\title{
A Case of Postpartum Psychosis in Male
}

\author{
${ }^{1}$ Amulya Bhaskara, ${ }^{2}$ Vishnuvardhan Gopalakrishnan
}

\begin{abstract}
Postpartum psychosis is a psychotic disorder that usually occurs in women who have recently delivered a baby. The syndrome is often characterized by the mother's depression, delusions, and thoughts of harming either herself or her infant. Postpartum psychosis in a male is however rarely observed. Hereby, we present this unusual case of 27-year-old male who developed psychosis just after the birth of his first child.
\end{abstract}

Keywords: Father, Postpartum, Psychosis.

How to cite this article: Bhaskara A, Gopalakrishnan V. A Case of Postpartum Psychosis in Male. J Med Sci 2018;4(4):107-108.

\section{Source of support: Nil}

\section{Conflict of interest: None}

\section{INTRODUCTION}

Postpartum psychosis is well-known to occur in women. ${ }^{1}$ Symptoms usually begin within a few days of delivery (mean time being 2-3 weeks) and can include fatigue, insomnia, restlessness, emotional lability, suspiciousness, confusion, denial of birth, thought of being unmarried, and hallucinations instructing the mother to kill the baby. $^{2}$

Just like the mothers, prospective fathers may also face certain psychological conflicts. ${ }^{3}$ There are not many studies or reports on psychological disturbances in males during the perinatal period. Among those reported, there are many on Couvade syndrome (pseudocyesis in males) and a few studies on depression in fathers during the perinatal period estimate $4-6 \%$ incidence in early pospartum period. ${ }^{4-6}$ Nevertheless, postpartum psychosis in males is not well recognized, and only a few such cases have been reported.,

\section{CLINICAL PRESENTATION}

A 27-year-old Indian male, with 10 years of formal education, married for past one year, presented one month after the birth of his male first child. The patient was

\footnotetext{
${ }^{1}$ Postgraduate Student, ${ }^{2}$ Professor and Head

1,2Department of Psychiatry, RajaRajeswari Medical College and Hospital, Bengaluru, Karnataka, India
}

Corresponding Author: Amulya Bhaskara, Postgraduate Student, Department of Psychiatry, RajaRajeswari Medical College and Hospital, Bengaluru, Karnataka, India, e-mail: amulyaanand92@gmail.com well until then, the moment he saw the face of the child, he felt that it did not resemble him, and consequently, denied that the child is his. Then on, he suspected that his wife had multiple affairs with other men and, to identify the child's father, he started comparing the face of the newborn child with the faces of his wife's male acquaintances in photographs. He feared that, since he began to question his wife's infidelity, her relatives wanted to kill him. After this, whenever he saw her relatives talking among themselves, he suspected that they were plotting against him. Apart from his wife, his suspicions of immorality and infidelity soon generalized to other female members in his family, namely his mother and sister. Over the next few days, his beliefs gained strength, and he demanded that either his wife divorce him and take the child with her, or she abandons the child if she wished to continue staying with him. Whenever his family members told him that the child was his, he would become aggressive and abusive towards them. As his symptoms worsened, he demanded to get a deoxyribonucleic acid (DNA) test done to prove that the child is not his, for which he was brought to the hospital. He did not abuse any substances. There is no history suggestive of schizophrenia or mood disorders. There is no significant past or family history.

During the interview, he was alert and well oriented, appeared dysphoric and was preoccupied with thoughts of proving that his child was not his. His general physical and neurological examination was within normal limits. His magnetic resonance imaging (MRI) brain and relevant laboratory investigation reports were within the normal limits.

The patient was admitted and treated with a daily dose of $20 \mathrm{mg}$ of olanzapine orally, to which he responded adequately. He became asymptomatic within 3 weeks, following which he was discharged and was asked to continue the same medication at the same dosage.

\section{DISCUSSION}

In this case, the patient developed psychosis following the birth of his first child. The stress of taking up the new role of a father, and other possible psychological factors like the baseless notion that his child should look only like him, could have led to the development of his symptoms.

Psychosis in males following the birth of their child can lead to the abandonment of the child or child murder. ${ }^{1}$ 
The likelihood of fathers developing psychological distress during the puerperal period is associated with factors like poor marital relationship and poor social networks. ${ }^{3}$ Symptom manifestation in such cases depends on how the prospective fathers appraise the event of childbirth in their life. Some men consider that getting a woman pregnant is proof of their potency. Some of them fear neglect from their wives once they have a child, while some others, may see the newborn child as a rival. ${ }^{2}$ Identifying and addressing the psychosocial factors that could lead to psychological distress during puerperal period plays an important role in prevention and management of this condition. ${ }^{6}$

\section{CONCLUSION}

Men are submitted to the same risks as women for developing psychosis in the postpartum period. ${ }^{1}$ It is important to prepare prospective fathers for the change in role and responsibility that comes with the birth of a child. It is also important to recognize and treat this condition in affected persons, for their well-being, and that of their child and family.

\section{REFERENCES}

1. Colombel M, Rebillard C, Nathou C, Dollfus S. Psychose puerpérale chez l'homme: une entité diagnostique?. L'Encéphale. 2016 Aug 1;42(4):386-389.

2. Sadock B, Sadock B, Sadock V, Ruiz P. Kaplan and sadock's synopsis of psychiatry. 11th ed. Philadelphia: Lippincott Williams \& Wilkins; 2015.

3. Boyce P, Condon J, Barton J, Corkindale C. First-time fathers' study: psychological distress in expectant fathers during pregnancy. Aust N Z J Psychiatry 2007;41(9):718-725.

4. Ballard CG, Davis R, Cullen PC, Mohan RN, Dean C. Prevalence of postnatal psychiatric morbidity in mothers and fathers. Br J Psychiatry 1994;164:782-788.

5. Areias ME, Kumar R, Barros H, Figueiredo E. Comparative incidence of depression in women and men, during pregnancy and after childbirth. Validation of the Edinburgh Postnatal Depression Scale in Portuguese mothers. Br J Psychiatry 1996;169:30-35.

6. Shahani L. A father with postpartum psychosis. BMJ case reports. 2012 May 8;2012:bcr1120115176.

7. Shapiro S, Nass J. Postpartum psychosis in the male. Psychopathology. 1986;19(3):138-142.

8. Davenport YB, Adland ML. Postpartum psychoses in female and male bipolar manic-depressive patients. Am J Orthopsychiatry 1982;52:288-297. 